\section{Ragam Interjeksi Bahasa Jepang}

\author{
Diah Soelistyowati \\ Program Studi Sastra Jepang \\ Universitas Dian Nuswantoro Semarang \\ dyah.soelistyowati@dsn.dinus.ac.id
}

\begin{abstract}
ABSTRAK
Penelitian ini bertujuan untuk mendeskripsikan ragam dan makna pada interjeksi bahasa Jepang (kandoushi). Data dianalisis dengan menggunakan metode deskriptif kualitatif dengan pendekatan kajian semantik. Data yang digunakan pada penelitian ini adalah kandoushi dalam percakapan yang dituturkan oleh tokoh yang terdapat dalam cerita pendek Shiro karya Akutagawa Ryunosuke. Data tersebut kemudian dianalisis menggunakan teori kandoushi milik Namatame. Hasil dari penelitian ini ditemukan beberapa ragam kandoushi berupa ajakan, memberitahu, saran, dan permintaan. Interjeksi bahasa Jepang digunakan dalam situasi informal dan digunakan oleh penutur kepada mitra tutur yang memiliki hubungan dekat.
\end{abstract}

Kata Kunci: Interjeksi bahasa Jepang; ragam Kandoushi; Namatame.

\title{
PENDAHULUAN
}

Setiap bahasa dalam berkomunikasi menggunakan beberapa ungkapan untuk menyampaikan suatu gagasan, ide maupun pikiran. Pada percakapan sehari-hari untuk menyampaikan ekspresi terhadap sesuatu terkadang menggunakan kata seru seperti, ah, wah, eh, sebagai ungkapan perasaan yang ingin disampaikan.

Interjeksi atau kata seru adalah kata yang berfungsi mengungkapkan perasaan. Di dalam kalimat interjeksi diikuti tanda koma, pada umumnya interjeksi mengacu pada sikap: (1) Negatif (meremehkan), misalnya cih,cis, bah,idih, sialan,brengsek; (2) Positif (memuji), misalnya aduhai, amboi, asyik, Insya Allah, syukur; (3) Keheranan, misalnya aih, Iho, astagfirullah, masya Allah, eh, oh, astaga; (4) Mengajak, misalnya ayo, ya, mari; (5) Bersifat fatis, misalnya hai, hallo, wah-wah, nah. Selain itu, menurut Djajasudarma (1993:47), interjeksi cenderung memiliki makna leksikal yang berhubungan dengan perasaan dan merupakan cermin ekspresi rasa yang sebenarnya dialami oleh pembicara. Hal ini menarik para peneliti pada tataran kalimat. Materi ini berhubungan dengan kalimat (wacana) sehingga dapat dilihat kalimat apa dengan menggunakan unsur interjeksi yang mana, pada situasi bagaimana secara pragmatis (hubungan pembicara dengan kawan bicara). Ditambahkan pula berdasarkan Kridalaksana (1993:84) interjeksi (interjection) adalah bentuk yang tak dapat diberi afiks dan yang tidak mempunyai dukungan sintaksis dengan bentuk lain, dan yang dipakai untuk mengungkapkan perasaan.

Dalam gramatika bahasa Jepang interjeksi atau kata seru disebut dengan 感動詞 (kandoushi). Kandoushi terdiri dari 3 (tiga) huruf kanji yaitu kanji 感 (kan) berarti perasaan; sensasi; sentimen; indera; emosi; kesan; intuisi. Kanji 動 (dou) bermakna gerakan; perubahan; kekacauan dan kanji 詞 (shi) artinya kata-kata (Nelson,2006:406;208;826), sehingga makna kandoushi adalah kata yang mengungkapkan suatu perasaaan atau emosi. Kandoushi berfungsi untuk membantu mengungkapkan perasaan dari penutur. Oleh karena itu kandoushi dengan sendirinya dapat menjadi sebuah kalimat dikarenakan kandoushi sudah mewakili keseluruhan perasaan dari penutur. Tujuan penelitian ini adalah untuk mengetahui bentuk, jenis dan makna pada interjeksi bahasa Jepang (kandoushi). Pada penelitian ini akan dibahas ragam interjeksi bahasa Jepang serta maknanya dalam bahasa Indonesia, sehingga diharapkan pembaca dapat memahami penggunaan interjeksi bahasa Jepang dan padanannya dalam bahasa Indonesia. 
Penelitian yang membahas tentang interjeksi (kandoushi) sudah banyak dilakukan, antara lain penelitian oleh Riche Karnilla, Syahrial, Anwar Nasihin berjudul "Fungsi Kata Seru (Kandoushi) Dalam Komik Detektif Conan vol.71 Karya Aoyama Gosho." Hasil penelitiannya sumber data dari komik Detektif Conan dianalisis menggunakan teori Yuki Ogawa untuk memaparkan fungsi dari kandoushi dan makna yang terdapat pada komik tersebut.

Berdasarkan penelitian tersebut, penulis ingin meneliti tentang ragam interjeksi (kandoushi) dalam bahasa Jepang. Perbedaan penelitian ini dengan penelitian sebelumnya adalah penulis menganalisis ragam kandoushi apa saja yang terdapat dalam teks bahasa Jepang pada cerita pendek berjudul Shiro karya Akutagawa Ryunosuke berdasarkan teori Namatame.

Semantik adalah 1. bagian struktur bahasa yang berhubungan dengan makna ungkapan dan juga dengan struktur makna suatu wicara; 2. sistem dan penyelidikan makna dan arti dalam suatu bahasa atau bahasa pada umumnya. Sedangkan makna leksikal yaitu penyelidikan makna unsur-unsur kosakata suatu bahasa pada umumnya (Kridalaksana, 1993:193-194). Dalam bahasa Indonesia ada kata-kata yang mempunyai makna leksikal, tetapi ada pula kata-kata yang dapat ditentukan maknanya jika kata tersebut telah berada dalam satuan yang disebut kalimat. Itu sebabnya kata-kata seperti itu disebut kata yang terikat konteks. Kata-kata seperti ini akan memiliki makna jika didampingi kata yang lain, apakah di depan atau berada di belakang kata tersebut. (Pateda, 2001:147)

Pengertian kandoushi menurut Ogawa (1982:141) berikut ini,

品
詞の一種。感嘆詞、感投詞などの呼称もある。独立語として文の初めに置
かれるか、独立した一語文として使用される（まれに文の中間に現れる）
。驚き、疑問, 当感、などの感情か、注意、制止、勧誘、呼びか、、
応答などの意志を直接的に表現した語。
Hinshi no isshu. Kantanshi, kantoushi nado no koshou mo aru. Dokuritsugo toshite
bun no hajimeni okareruka, dokuritsushita ichigobun toshite shiyousareru (mareni bun
no chuukan ni arawareru). Odoroki, gimon, toukan, nado no kanjou ka, chuvi, seishi,
kanyuu, yobikake, ootou nado no ishi wo chokusetsuteki ni hyougenshita go.
'Kandoushi merupakan jenis kata yang juga disebut kantanshi atau kantoushi. Kata
yang diletakkan di awal kalimat sebagai kata yang berdiri sendiri (walaupun masih
terlihat hubungannya dalam kalimat itu). Kata yang diungkapkan secara langsung
yang mengungkapkan impresi (perasaan terkejut, bertanya-tanya dan lain-lain),
seruan, larangan, ajakan, panggilan, jawaban dan lain-lain.

Berdasarkan penggunaannya Kandoushi mempunnyai beberapa fungsi antara lain : (1) Kandou, mengungkapkan perasaan kecewa, terkejut, marah dan kagum : a, ara, maa, yatsu, hoo, he, oya, yare-yare, saa.; (2) Yobikake, merupakan ungkapan perasaan panggilan : moshimoshi, oi, yai, ano, chotto,nee, naa,saa; (3) Outou, merupakan ungkapan jawaban dan balasan : ee, hai, haa, iie, un, iya, e, nani; (4) Aisatsu, merupakan ungkapan salam : ohayou, konnichiwa, konbanwa, sayonara, arigatou; (5) Kakegoe, merupakan ungkapan seruan untuk memberi semangat : dokkoisho, yoissa, hoikita, hore, sore.

Menurut Namatame (1996:197) kandoushi adalah:

感動詞はそれだけでーつの文となり、感動の内容を全部表すことができる が、感動の内容を感動詞のあとに置く場合も多い。

Kandoushi ha sore dake de hitotsu no bun to nari, kandou no naiyou wo zenbu arawasu koto ga dekiru ga, kandou no naiyou wo kandoushi noato ni oku baai mo ooi.

'Kandoushi dapat berdiri sendiri sebagai kalimat, dan semua isi perasaan dapat diungkapkan, tetapi banyak keadaan di mana isi dari perasaan tersebut diletakkan setelah kandoushi.' 
Namatame dalam Nihongo Kyoushi no Tame no Gendai Nihongo Hyougen Bunten (1996:197-203) membagi kandoushi menjadi:

1. Kandoushi yang menunjukkan keterkejutan

a. saat pertemuan atau kejadian yang tiba-tiba

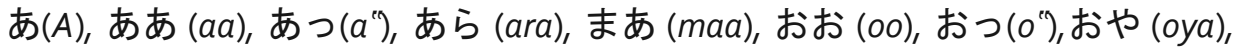
わあ(waa), わっ $\left(w a^{\prime}\right)$.

b. saat mendapat informasi berupa perubahan atau sesuatu yang tidak dimengerti

あれ(are)，おや(oya)，おやおや(oyaoya)，えつ(e")

c. jika informasi yang diterima dirasakan secara mendalam

ええ(Ee), へえ(hee), まあ(maa),ふーん(fuun),ほう(hou).

2. Kandoushi yang menunjukkan kebahagiaan

ああ(Aa)，あら $(a r a)$ ，まあ(maa)，わ(わっ) $\left(w a\left(w a^{*}\right)\right.$.

3. Kandoushi yang menunjukkan kesedihan

ああ $(A a)$, おお $(o o)$.

4. Kandoushi untuk menunjukkan perasaan kecewa dan penyesalan

やれやれ(Yareyare), おやおや (oyaoya)，あれあれ(areare).

5. Kandoushi untuk menunjukkan kebahagian atas keberhasilan よかった(Yokatta)，やった(yatta)，しめた(shimeta).

6. Kandoushi yang menunjukkan perasaan pengabaian dan penghinaan なにさ(Nanisa)，ふん (fun), へっ(he")，なんだ(nanda).

7. Kandoushi untuk menghina lawan bicara ばかやろう(Bakayarou),ばか(baka),このやろう(konoyarou).

8. Kandoushi ketika tertawa あはは(Ahaha), わはは(wahaha),ふふふ(fufufu).

9. Kandoushi ketika menjerit きゃっ (Kya")，(わっ(わあ)wa"(waa)).

10. Kandoushi yang menunjukkan ekspresi penyemangat どこいしょ(Dokoisho),よいしょ(yoisho), わっしょい(wasshoi).

11. Kandoushi panggilan

もしもし (Moshimoshi), ちょっと(chotto),よう(you),なあ(naa), おい(oi), やい(yai), こら (kora).

12. Kandoushi yang digunakan untuk mengajak atau mendesak さ(さあ) (Sa (saa)), ねえ(nee), よう(you).

13. Kandoushi yang berupa komando atau peringatan そら(Sora)，それ(sore),ほら(hora).

14. Kandoushi yang ditunjukkan apabila sedang memikirkan sesuatu え一と(Eeto), さあ(saa), はて(hate).

Teori kandoushi yang diutarakan oleh Namatame menjelaskan bahwa dengan satu kata kandoushi penutur dapat mengutarakan perasaannya. Penggunaan kandoushi pun sering disertai dengan kata atau kalimat setelahnya, yang membantu memperjelas pengungkapan ekspresi penutur.

Kandoushi merupakan salah satu kelas kata yang termasuk jiritsugo yang tidak dapat berubah bentuknya, tidak dapat menjadi subjek, tidak dapat menjadi keterangan, tidak pula dapat menjadi konjugasi. Kandoushi bukanlah sebuah subjek ataupun predikat, kandoushi juga tidak dapat ditambah dengan keterangan kata-kata lain sehingga kandoushi tanpa bantuan kelas kata lain dapat menjadi sebuah kalimat sendiri. Kandoushi juga selalu terletak di awal kalimat. Berdasarkan pengertian-pengertian tentang interjeksi (kandoushi) di atas, dapat disimpulkan 
bahwa kandoushi merupakan kata tunggal yang ada di awal kalimat dan dapat berdiri sendiri, sehingga dengan sendirinya dapat menjadi sebuah kalimat walaupun tanpa dibantu dengan kalas kata yang lain. Kandoushi tidak dapat berfungsi sebagai subyek, predikat, maupun obyek dan tidak dapat berfungsi sebagai konjugasi. Kandoushi adalah kata yang berdiri sendiri hanya berfungsi sebagai kata tunggal yang sifatnya bebas. Selain itu kata yang diungkapkan mengandung bermacam-macam perasaan pembicara seperti perasaan terkejut, bingung, heran, dan juga sebagai kata salam, ajakan, panggilan, jawaban dan lain-lain.

Metode penelitian yang digunakan pada penelitian ini menggunakan pendekatan penelitian kualitatif. Penelitian kualitatif menurut Bogdan dan Biklen dalam Sugiyono (2010:11) adalah penelitian yang digunakan pada data berupa teks baik dalam koran, anime, novel, film, drama dan bukan data angka. Selain itu, penelitian kualitatif merupakan penelitian yang bersifat deskripsi. Metode deskriptif digunakan semata-mata hanya berdasarkan fakta yang ada atau fenomena yang memang secara empiris masih digunakan oleh penuturnya, sehingga dapat dipaparkan seperti apa adanya (Sudaryanto, 1992:62). Sumber data yang digunakan dalam penelitian ini adalah teks dari cerita pendek bahasa Jepang berjudul Shiro karya Akutagawa Ryunosuke. Cerita pendek ini digunakan karena terdapat beberapa interjeksi yang dapat dianalisis sebagai data dalam penelitian ini. Cerita ini mengisahkan tentang seekor anjing putih bernama Shiro. Warnanya berubah menjadi hitam setelah meninggalkan Kuro teman baiknya yang mati oleh penangkap anjing. Perubahan warna disebabkan oleh faktor malu dan merasa dirinya pengecut dan menjadi merasa bersalah pada dirinya sendiri hingga ingin bunuh diri. Kedua majikan kecilnya mengusirnya karena tidak mengenali warna bulunya yang sudah berubah menjadi hitam. Akhirnya setelah mengembara, Shiro memutuskan untuk kembali menemui kedua majikan kecilnya terakhir kalinya sebelum ingin bunuh diri. Keesokan harinya Shiro terkejut ketika terbangun dari tidurnya kedua majikan sudah berdiri didepannya. Kedua majikannya pun terkejut melihat Shiro sudah kembali pulang ke rumah. Warna kulit Shiro yang tadinya hitam kembali ke warna semula menjadi putih, sehingga Shiro diterima kembali oleh keluarga itu. Data dikumpulkan dan dianalisis menggunakan metode penelitian deskriptif. Teknik analisis data diterapkan dengan langkah-langkah sebagai berikut. Dalam analisis data menggunakan teknik deskriptif dari Miles dan Hubermen dalam Sugiyono (2011:246) berupa tiga tahapan, yaitu reduksi data, penyajian data dan verifikasi data untuk menganalisis data. Dalam penelitian ini metode yang digunakan adalah metode padan. Metode padan alat penentunya diluar, terlepas dan tidak menjadi bagian dari bahasa bersangkutan. (Sudaryanto, 1993:13) Metode padan ini digunakan untuk menganalisis padanan interjeksi (kandoushi) dalam bahasa Jepang ke dalam bahasa Indonesia. Data pada penelitian ini diklasifikasikan menurut jenisnya berdasarkan teori yang dikemukakan oleh Namatame dan untuk menjelaskan padanan makna dari kandoushi tersebut digunakan kamus Kokugo Jiten dan Nihongo-Indonesiago Jiten.

\section{ANALISIS DAN PEMBAHASAN}

Berdasarkan teori Namatame interjeksi dalam bahasa Jepang yang ditemukan pada data-data dari cerita pendek Shiro karya Akutagawa Ryunosuke dianalisis sebagai berikut:

1. Kandoushi yang menunjukkan keterkejutan

（1）白はただ恍惚とこの犬の姿に見入りました。

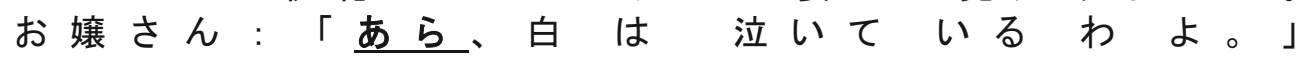
お嬢さんは白を抱きしめたまま、坊ちゃんの顔を見上げました。 Shiro wa tada koukotsu to kono inu no sugata ni miirimashita.

Ojousan: "Ara, shiro wa naite iru wa yo"

Ojousan wa shiro wo dakishimeta mama,bouchan no kao wo miagemashita.

'Si Putih menatap anjing ini dengan perasaan gembira.

Gadis kecil : "Aaah, si putih sedang menangis ya"

Gadis kecil itu mendongak ke atas melihat saudaranya sambil terus memeluk si Putih.'

Menurut Kindaichi (1996:34) あら 感・驚いた時に女性が出す言葉とも言えない声。「あ らまあ」長呼して「ああら」とも言う。(Ara kan • odoroita toki ni jousei ga dasu kotoba to 
mo ienai koe). Interjeksi あら Ara merupakan suara yang tidak dapat dikatakan sebagai kata yang digunakan wanita mengekspresikan ketika sedang terkejut, dari asalnya ああら aara yang dipanjangkan menjadi あらまあ aramaa. Interjeksi ini dipadankan ke dalam bahasa Indonesia 'aaah'. Pada data (1) si Putih telah kembali pulang kerumahnya, setelah sekian lama menghilang. Hal itu membuat pemilik anjing Ojousan 'gadis kecil' terkejut dan dia pun kaget melihat Si Putih menangis, sehingga menggunakan interjeksi ara untuk mengungkapkan ekspresi keheranan karena terkejut melihat Si Putih yang tiba-tiba menangis. Kemudian Ojoousan memeluk si Putih sambil melihat wajah Bouchan 'anak laki-laki' dengan wajah terharu.

（2）白は寂しそうにため息をしました。「じゃもうおじさんは家へ帰ろう。」 子犬：「まあ、お待ちなさい。おじさんの御主人はやかましいのですか」 Shiro wa sabishisouni tameiki wo shimashita.(Ja, mou ojisan wa ie he kaerou) Koinu : (Maa, omachinasai. Ojisan no goshujin wa yakamashii no desu ka.) 'Si putih menghela napas kelihatan sedih. "kalo begitu, ayo pulang ke rumah"?' Anak anjing :'Wah, tunggu sebentar. Apakah pemilik si putih cerewet?'

Berdasarkan Kindaichi (1996:1209) まあ感・（女性語）意外な事を初めて知った時などに出す 事。（まあ、驚いた） (Maa kan •(jouseigo) igai na koto wo hajimete shitta toki nado ni dasu koto (maa, odoroita) ). Interjeksi maa merupakan bahasa yang digunakan wanita untuk mengungkapkan ekspresi yang terjadi ketika pertama kali mengetahui sesuatu hal yang tidak terduga. Interjeksi maa digunakan untuk mengungkapkan perasaan seperti ungkapan terkejut, heran maupun ungkapan kekaguman terhadap sesuatu. Interjeksi ini tidak hanya menunjukkan rasa terkejut tetapi juga menunjukkan perasaan kebahagiaan. Maa dalam bahasa Indonesia dapat dipadankan dengan wah, aduhai dan amboi. Ketika anak anjing menanyakan keberadaan si Putih akan tinggal dimana, si Putih terlihat dengan muka sedih menjawab akan kembali pulang ke rumahnya. Jawaban yang tidak terduga karena tidak menyangka si Putih akan pulang ke rumah pemiliknya, maka membuat anak anjing tersebut terkejut dan menggunakan interjeksi maa (data 2) untuk menanyakan keterkejutannya mengetahui si Putih ingin kembali ke rumah pemiliknya yang cerewet.

（3）けれどもそれが何になりましょう? あの自動車をご覧なさい。 ええ、あの公園の外にとまった、大きい黒塗りの自動車です。 漆を光らせた自動車の車体は今こちらへ歩いて来る白の姿を映しました。 Keredomo sore ga nani ni narimashou?Ano jidousha wo gorannasai.

Ee, ano kouen no soto ni tomatta, ookii kuronuri no jidousha desu.

Urushi wo hikaraseta jidousha no shatai wa ima kochira he aruite kuru shiro no sugata wo utsushimashita.

'Akan tetapi, itu menjadi apa ya? Lihat mobil itu!

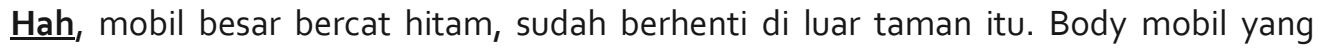
disinari pernis sekarang membayangkan badan si putih yang datang berjalan ke sini.'

Menurut Kindaichi (1996: 123) ええ、感・すぐに言葉や考えが出ないで、少し考える時に出す 言葉。(Ee, kan · suguni kotoba ya kangae ga denai de, sukoshi kangaeru toki ni dasu kotoba). Ragam berikut adalah kata yang diucapkan ketika tidak dapat mengeluarkan suatu kata atau tidak terpikirkan, digunakan kandoushi ee apabila merasa terkejut saat mendengar perkataan orang lain. Matsura (2005:159) mengutarakan bahwa kandoushi ee「ええ」 memiliki padanan makna "eh", "ha", "heh", dan "hah". Data (3) mengekpresikan keterkejutan penulis ketika melihat si Putih yang menghampiri mobil besar berwarna hitam yang mengkilap untuk bercermin, karena penulis mengetahui bahwa selama ini si Putih selalu menghindar melihat dirinya melalui cermin. Si Putih tidak bisa lupa warna kulitnya yang menjadi hitam, sehingga pemiliknya menganggap bahwa anjing miliknya bukan si Putih. Si Putih sangat takut melihat bayangan dirinya sendiri di cermin dan segala sesuatu yang bisa terlihat badannya yang berwarna hitam seperti melihat cermin tukang pangkas rambut yang mencerminkan wajah para pelanggan, takut akan genangan air di jalanan yang 
memantulkan langit setelah turun hujan, takut dengan jendela kaca yang memantulkan dedaunan hijau dari pohon-pohon di jalanan, bahkan merasa takut juga dengan gelas-gelas bir hitam di atas meja kafe. Oleh karena itu, merasa heran melihat si Putih yang ketakutan melihat badannya yang hitam tetapi justru menghampiri mobil bercat hitam itu.

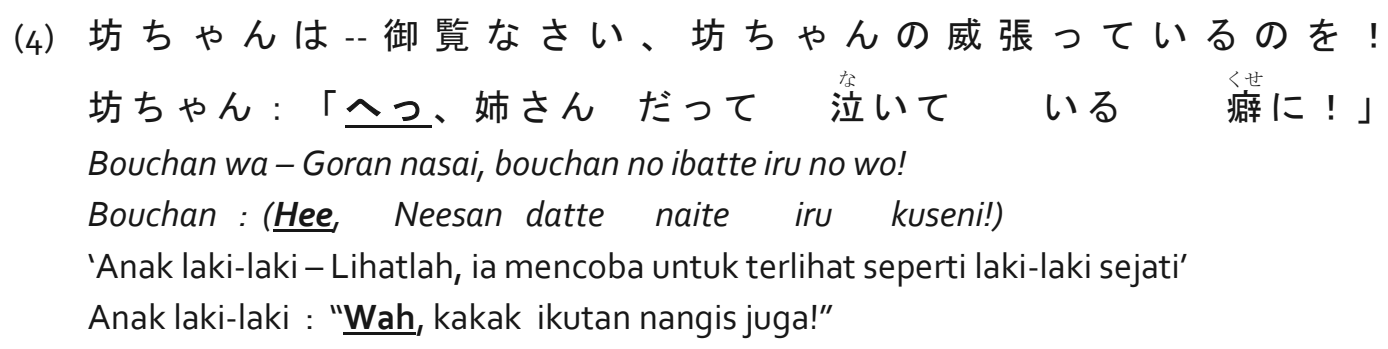

Kindaichi (1996: 1163) menguraikan bahwa ヘえ、感 · 感心したり驚いたり少し疑ったりあきれ たりした時などに出す、言葉にならない言葉 (Hee, kan · kanshin shitari odoroita sukoshi utagattari akiretari shita toki nado ni dasu, kotoba ni naranai kotoba ). Kandoushi hee mengungkapkan perasaan ketika heran atau sesuatu yang meragukan, terkejut atau sesuatu kata yang tidak dapat dikatakan.' Anak laki-laki sangat senang melihat si Putih bagaikan laki-laki sejati kembali pulang ke rumahnya, sehingga membuat gadis kecil terharu. Data (4) digunakan anak kecil itu mengekspresikan keterkejutannya melihat gadis kecil tersebut menjadi menangis juga.

\section{Kandoushi yang menunjukkan kesedihan}

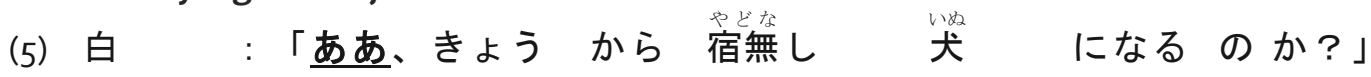
白はため息を洩らしたまま、しばらくはただ電柱の下にぼんやり空を眺めてい ました。

Shiro :

"Aa, kyou kara yadonashi inu ninaru noka?"

Shiro wa tameiki wo morashitamama, shibaraku wa tada denchuu no shita ni bonyari sora wo nagamete imashita.

Si Putih : 'Aduh, apakah mulai hari ini saya jadi anjing yang tidak punya rumah?

'Si putih menghela napas, sementara itu sambil melamun melihat ke langit di bawah tiang listrik'

Kindaichi (1996:1) ああ 感 - 肯定 - 承知を意味する声。物事に感じて出す声。「驚き・悲 しみ・喜び・嘆きなどを表す。」(Aakan・koutei · shouchi wo imi suru koe. Monogoto ni kanjite dasu koe. (Odoroki - kanashimi "yorokobi " nageki nado wo arawasu) Kandoushi aa untuk menunjukkan ungkapan ketika mengeluh, gembira, sedih, kaget suara yang dikeluarkan ketika terharu, suara yang bermakna setuju atau membenarkan. Interjeksi aa dalam bahasa Indonesia dapat dipadankan dengan aduh, ah, huh dalam Matsuura (1996:1). Data (5) di atas, kandoushi aa digunakan untuk menyatakan ekspresi terkejut atau kaget ketika melihat sesuatu yang aneh atau suatu hal di luar perkiraan. Interjeksi ini menunjukkan perasaan kaget disebabkan si Putih merasa sudah tidak mempunyai tempat tinggal lagi seperti dulu.

\section{Kandoushi yang berupa komando atau peringatan}

（6）御 覧な さい。坂をを 駆け 降りりるす 著者：そら、自動車に惹かれそうになりました! 白はもう命の助かりさに夢中になっているのかもしれません。 Goran nasai. Saka wo kakeoriru no wo!

Chosha : Sora, jidousha ni hikaresou ni narimashita.

Shiro wa mou inochi no tasukarisani muchuu ni natte iru no kamoshiremasen.

'Lihatlah. Bergegas menuruni bukit!

Pengarang : $\underline{\text { Nah, }}$ sepertinya tertabrak mobil.

Si Putih mungkin mati tetapi nyawanya masih tertolong ' 
Kindaichi (1996:746) そら 感・（相手の注意を強く喚起したり自分自身の気持を引き締めた りすることを表す Sora kan · aite no chuvi wo tsuyoku kankishitari jibun jishin no kimochi wo hikishimetari suru koto wo arawasu. Kandoushi sora menunjukkan bahwa perasaannya sendiri diperketat dan menekankan perhatian pada pihak lain. Pengarang mengkhawatirkan si Putih yang berlari-lari menuruni bukit. Kecemasan pengarang ditunjukkan pada data (6) dengan menggunakan kandoushi sora dalam Matsuura (2005:991) yang berarti 'nah' untuk memberikan peringatan bahwa si Putih terlihat tertabrak mobil. Akan tetapi, beruntung nyawa si Putih masih tertolong.

\section{Kandoushi yang ditunjukkan apabila sedang memikirkan sesuatu}

（7）は二三間追いかけた後、くるりと子犬を振り返ると、叱るようにこう声をかけ ました。

白：「さあ、おれとーしょに来い。お前の家まで 送ってやるから。」

Shiro wa ni san ken oikaketa ato, kururi to koinu wo furikaeru to, shikaru youni kou koe wo kakemashita.

Shiro: (Saa, ore to isshoni koi. Omae no ie made okutte yarukara)

'Si Putih setelah mengejar sekitar 2 - 3 meter, menoleh ke anak anjing dengan suara seperti marah'

Si Putih : "Ayo, ikut saya. Karena saya akan mengantarkanmu sampai ke rumah."

Kandoushi saa menurut Kindaichi (1996: 462)さあ 感・（新たな事態に出会ってなんらかの たいおう せま せっきょくてき

対応を迫られた時や積極的に行動を起こそうとする時などに）他人や自分に言って聞か せるつもりで発する語・さあ、大変だ。Saa kan · (aratana jitai ni deatte nanraka no taiou wo semarareta toki ya sekkyouteki ni koudou wo okosou to suru toki nado ni) tanin ya jibun ni itte kikaseru tsumori de hassuru go. Kandoushi saa diucapkan ketika harus memberikan tanggapan terhadap suatu kejadian yang baru atau ketika terjadinya situasi keadaan yang positif. Setelah mengejar anak anjing yang berjarak sekitar $2-3$ meter, si Putih menoleh ke belakang sambil bersuara dengan nada seperti marah mengajak anak anjing untuk pulang kerumahnya. Kemudian si Putih menggunakan kandoushi saa dalam Matsuura (2005:826) mempunyai padanan arti 'Ayo, mari'. Data (7) ini digunakan si Putih untuk mengajak anak anjing mengantarkannya kembali ke rumah.

\section{KESIMPULAN}

Berdasarkan data-data di atas, dapat disimpulkan bahwa interjeksi yang digunakan dalam bahasa Jepang mempunyai bermacam-macam ungkapan untuk menunjukkan ekspresi dari ucapan yang disampaikan pada suatu kalimat. Kandoushi digunakan oleh penutur kepada mitra tutur yang memiliki hubungan dekat dalam situasi informal. Adapun ragam interjeksi yang ditemukan pada data-data tersebut berupa ajakan, memberitahu, saran, dan permintaan, seperti kandoushi yang menyatakan keterkejutan, menunjukkan kesedihan, memberi peringatan dan ketika memikirkan sesuatu.

\section{DAFTAR PUSTAKA}

Djajasudarma, T. Fatimah Dr. 1993. Metode Linguistik. Ancangan Metode Penelitian dan Kajian. Bandung: Eresco.

Karnilla Riche, Syahrial, Anwar Nasihin. 2013. Fungsi Kata Seru (Kandoushi) Dalam Komik Detektif Conan vol.71 Karya Aoyama Gosho. Artikel Ilmiah Hasil Penelitian Mahasiswa Jurusan Sastra Asia Timur vol 2, No 3

Kindaichi, Kyousuke dll. 1996. Shinmeikai Kokugo Jiten. Japan: Sanseido.

Kridalaksana, Harimurti. 1993. Kamus Linguistik. Jakarta: Gramedia Pustaka Utama.

Masuoka, Takashi, dan Yukinori Takubo. 1989. Kiso Nihongo Bunpou. Tokyo: Kuroshio Shuppan

Masayoshi, Arai. 1989. Kokugo Jiten. Tokyo: Obunsha. 
Matsuura, Kenji. 1994. Nihongo-Indonesiago Jiten. Kyoto, Japan: Kyoto Sangyo Universsity Press

Namatame, Y. 1996. Nihongo Kyoushi No Tame No Gendai Nihongo Hyougen Bunten. Jepang: Bonjinsha.

Nelson, Andrew N. 2006. Kamus Kanji Modern Jepang Indonesia. Jakarta: Keisant Blanc

Ogawa, Yuuki. 1982. Nihongo Kyooviku Jiten. Japan: Taishukan Publishing Company.

Sudaryanto. 1992. Metode Linguistik. Yogyakarta: Gadjah Mada University Press.

1993. Metode dan Aneka Teknik Analisis Bahasa. Yogyakarta: Duta Wacana University Press.

Sugiyono. 2011. Metode Penelitian Kuantitatif, Kualitatif, dan R \& D. Bandung: Alfabeta.

Pateda, Mansoer. 2001. Semantik Leksikal. Jakarta: Rineka Cipta. 